\title{
Katarzyna Badowska*
}

iD https://orcid.org/0000-0002-6149-5612

\section{Mit orfejski à rebours \\ O Pieśni tryumfującej miłości Tadeusza Micińskiego}

Głęboka fascynacja, z jaką literaci Młodej Polski studiowali tajniki muzyki oraz transponowali język dźwięków na grunt sztuki słowa, nie ominęła również Tadeusza Micińskiego. Powszechnie wiadomo, iż autor Nietoty żył w przyjaźni z Karolem Szymanowskim, a warto przypomnieć, iż utrzymywał kontakty także z innymi kompozy torami - Adamem Wieniawskim, z którym mieszkał podczas studiów w Berlinie rozpoczętych w roku 1896, Mikalojusem Čiurlionisem, z którym dyskutował o sztuce podczas „herbatek poziomkowych” u dyrektora warszawskiej ASP, z Ludomirem Różyckim, Mieczysławem Karłowiczem, Grzegorzem Fitelbergiem oraz Apolinarym Szelutą, z którymi przebywał w Zakopanem w 1905 r. i uznanie dla których wyraził w słowach wstępnych do pisanego kilka lat później dramatu $W$ mrokach złotego pałacu, czyli Bazilissa Teofanu'. Wielkim przeżyciem była dla pisarza wizyta w Instytucie Jaques-Dalcroze’a w Hellerau koło Drezna, gdzie w czerwcu 1912 r. podpatrzył ideę teatru wcielającego koncepcję tzw. gimnastyki rytmicznej, entuzjastycznie zaprezentowaną następnie polskiemu czytelnikowi na łamach „Tygodnika Ilustrowanego"2. Dzieła Micińskiego potwierdzają erudycję muzyczną ich autora; zawierają wiele odwołań do rozmaitych pieśni i kompozycji narodowych (polskich, litewskich, niemieckich), w tym także ludowych, ireligijnych

* Dr, Uniwersytet Łódzki, Instytut Filologii Polskiej i Logopedii, Zakład Literatury Pozytywizmu i Młodej Polski, ul. Pomorska 171/173, 90-236 Łódź; e-mail: katarzyna.badowska@uni.lodz.pl

1 Zob. M. Gmys, Harmonie i dysonanse. Muzyka Młodej Polski wobec innych sztuk, Poznań 2012, s. 44-45; T. Chylińska, Karol Szymanowski i Tadeusz Miciński, w: Studia o Tadeuszu Micińskim, red. M. Podraza-Kwiatkowska, Wydawnictwo Literackie, Kraków 1979, s. 325-340. Pod wpływem lektury tomu $W$ mroku gwiazd wymienieni powyżej muzycy komponowali pieśni na głos i fortepian do słów wierszy Micińskiego.

2 T. Miciński, Życie i twórczość w Hellerau, „Tygodnik Illustrowany” 1912, nr 30 (z 27 lipca), s. 628-629. 
(np. w Menè-Menè-Thekel Upharisim!... odnajdujemy opis renesansowego hymnu Giovanniego da Palestrina, w Bazilissie Teofanu - wykonania psalmów) oraz czynią z nich tło dla wydarzeń scenicznych czy rozmów bohaterów (np. w Mścicielu Wenety Wanda gra Chopina). Xiądz Faust zawiera „imaginacyjną partyturę Zmierzchu bogów"3 Richarda Wagnera, zaś Termopile polskie opatrzył autor wiele mówiącą instrukcją dla inscenizatorów, zalecającą konkretną oprawę muzyczną poszczególnych partii dramatu, zanim nie doczeka się on własnej muzyki instrumentalnej - najbardziej pożądanej, ponieważ stworzonej dla niego, a więc harmonijnie $\mathrm{z}$ nim zespolonej ${ }^{4}$.

Twórcy przełomu XIX i XX w. cenili ten rodzaj muzyki, który ówczesny francuski psycholog i filozof Théodule Ribot określił „pełną” - miała to być muzyka opracowująca stany wewnętrzne i wyrażająca uczucia (w przeciwieństwie do muzyki opartej na zręcznej kombinacji tonów, dowodzącej wyłącznie technicznej biegłości, „pustej”) ${ }^{5}$. W takiej muzyce jest upojenie i ekstaza wiązana z żywiołem dionizyjskim, który Nietzsche sytuował w opozycji do apollińskiego charakteru sztuk przedstawieniowych. Taka muzyka ma moc magnetyzowania słuchacza, jest silnym narzędziem oddziaływania na jego emocje i psychikę, łączy wykonawcę i odbiorcę nawet poza ich świadomością, zdolna jest więc zarażać ich wzajemną miłością. Obezwładniającą moc dźwięków jako źródła oraz medium wzajemnej fascynacji akcentował Lew Tołstoj w głośnej Sonacie Kreutzerowskiej (1889). Bohater opowiadania, dostrzegając uczucie rodzące się podczas wspólnego muzykowania między jego żoną a znakomitym skrzypkiem, winą za zbliżenie obojga obarcza właśnie muzykę:

Stałby się pośmiewiskiem ktoś, kto by zwalczał zbliżenie na balach, [...] bliskość przy zajmowaniu się sztuką, malarstwem, a przede wszystkim - muzyką. Ludzie zajmują się we dwoje najszlachetniejszą sztuką, muzyką, do tego potrzebna jest pewna bliskość, w tej bliskości nie ma nic zdrożnego, i tylko głupi zazdrosny mąż może widzieć w tym coś niepożądanego. A przecież wszyscy wiedzą, że właśnie za

3 A. Wiedemann, Sytuacja muzyki współczesnej i wizje jej rozwoju w prozie powieściowej Młodej Polski, w: Stulecie Młodej Polski. Studia, pod red. M. Podrazy-Kwiatkowskiej, Wydawnictwo Literackie, Kraków 1995, s. 507.

4 Na temat obecności muzyki w dziele Micińskiego zob. m.in.: I. Sławińska, Miciński i Hellerau, w: Studia o Tadeuszu Micińskim, red. M. Podraza-Kwiatkowska, Wydawnictwo Literackie, Kraków 1979, s. 303-323; I. Nowak, Muzyka w dramatach Tadeusza Micińskiego, „Acta Universitatis Lodziensis. Folia Litteraria Polonica" 2012, nr 1, s. 45-57; M. Jastrząbek, Muzyka w dramatach Tadeusza Micińskiego na przykładzie „Termopili polskich”. Misterium na tle życia i śmierci Księcia Józefa Poniatowskiego, „Folia Litteraria Polonica” 2012, nr 1, s. 58-76; A. Wiedemann, dz. cyt.; I. Łodzińska, Twórczość Tadeusza Micińskiego w kontekście muzyki [praca doktorska obroniona w Instytucie Muzykologii UW, 2015].

5 Zob. T. Ribot, Logika uczuć, tłum. K. Błeszyński, Krakowska Spółka Wydawnicza, Kraków 1921, s. 177. 
pośrednictwem tych zajęć, zwłaszcza muzykowania, dochodzi do większości wypadków cudzołóstwa w naszej sferze ${ }^{6}$.

Odkrycia erototwórczej roli muzyki dokonywał również Stanisław Przybyszewski. Zazdrość o ukochaną zbyt namiętnie akompaniującą poecie czytającemu swój poemat dręczy bohatera utworu $Z$ cyklu Wigilii, zaś w powieści Synowie ziemi hipnotyzujące, uwodzicielskie działanie melodii płynącej z fortepianu zostaje cynicznie wykorzystane do zniewolenia i zgwałcenia zasłuchanej w dźwiękach kobiety.

Powiązanie muzyki i Erosa w interesującej kompozycyjnie oraz ideowo postaci odnajdujemy we wczesnym poemacie prozą Tadeusza Micińskiego, drukowanym w krakowskim „Życiu” w 1899 r. (nr 5)²: w Pieśni tryumfującej miłości. Jako istotny, choć niepodsuwany przez autora explicite, trop interpretacyjny nasuwa się czytelnikowi utworu mit o Orfeuszu, trackim muzyku i śpiewaku, uważanym za jednego z twórców muzyki greckiej, który mocą melodii próbował wyzwolić z krainy zmarłych ukochaną Eurydykę. Mit ten ma w poemacie charakter aluzyjny i ukryty, implikowany jest przez konstrukcję i rozpoznawalną motywikę, nie oznacza natomiast przyjęcia i rekonstrukcji gotowego wątku. Buduje znaczenia odpowiadające sytuacji jednostki przełomu wieków, stając się artystyczną refleksją o potrzebie wtajemniczenia we własną podmiotowość, inicjacji w „ja” przez miłość i muzykę o charakterze dionizyjskim, wprawiającą w stan upojenia, kierującą ku temu, co nieskończone, otwierającą na kontakt $\mathrm{z}$ absolutem ${ }^{8}$.

Pieśń tryumfującej miłości to monolog człowieka uwięzionego, rozpoczynający się pełnym boleści wykrzyknieniem, w którym streszcza się mizeria kondycji bohatera-narratora, zestawiona z nieskończonością kosmosu: „I tyle jedno pozostało mi szczęścia na tym bezgranicznym świecie, że mi dano czasem rozmawiać z gwiazdami!"9.

6 L. Tołstoj, Sonata Kreutzerowska, tłum. M. Leśniewska, Książka i Wiedza, Warszawa 1987, s. 150.

7 O perypetiach związanych z tym numerem „Życia”, a co za tym idzie i z Pieśnią tryumfującej miłości pisałam w nieco innej wersji tego artykułu: Eros et Musica - „Pieśń tryumfujacej miłości” jako opowieść o klęsce wyzwolin z egzystencjalnej pustki, w: Proza Tadeusza Micińskiego. Studia, red. nauk. M. Bajko, W. Gutowski, J. Ławski, Uniwersytet w Białymstoku, Białystok 2017, s. 379-380.

8 Jako ciekawostkę warto przypomnieć, że kilkanaście lat później w Hellerau Miciński oglądał operę Christopha Willibalda Glucka Orfeusz i Eurydyka, której - zachwycony - poświęcił w prasowej relacji wiele miejsca, określając spektakl m.in. jako "misterium godne Danta i Ajschylosa" (T. Miciński, Życie i twórczość w Hellerau, s. 629).

9 T. Miciński, Pieśn triumfującej miłości, w: tenże, Poematy proza, oprac. W. Gutowski, Wydawnictwo Literackie, Kraków 1985, s. 47. Dalej skrótowa lokalizacja cytatów z poematu za tym wydaniem, z podaniem w nawiasie numeru strony. 
Sytuacja uwięzienia jest niezwykle dojmująca, sądząc po skali emocji, i zapewne nie raz zajmowała myśli udręczonego nią człowieka, o czym świadczy inicjalny parataktyczny spójnik „i”, sugerujący uprzednie już podjęcie refleksji, której kontynuację stanowi niejako treść monologu-poematu. Pierwszy werset wydaje się bowiem ciągiem dalszym, uzupełnieniem, a po części nawet podsumowaniem jakichś niewyeksplikowanych utyskiwań na egzystencję tak bardzo naznaczoną cierpieniem, że wyłączną radością pozostaje możność spoglądania ku gwiazdom, w których bohater pragnie widzieć nie tylko świadka niedoli, ale też towarzysza, rozmówcę, odbiorcę swego rozpacznego wyznania, co poświadcza również padająca nieco dalej apostrofa: „O gwiazdy - jedyne powiernice mojej duszy” (s. 49).

Kwestia adresata owej pełnej skarg opowieści jest chyba w ogóle bardziej interesująca, niż to się może na pozór wydawać. Lamentacja jest bowiem ustrukturyzowana w taki sposób, jakby jej odbiorcą - poza czytelnikiem rzecz jasna - miał być ktoś ze świata przedstawionego. Bohater-narrator wyraźnie stara się nadać jej formę, uładzić z myślą o słuchaczu. Jego monolog nie jest rejestrem luźnych skojarzeń ani zapisem wyrywkowych, akcydentalnych wrażeń czy wspomnień przebytych doświadczeń - jak w XIX-wiecznej prozie mogłoby przebiegać wewnętrzne wyłącznie, podświadomościowe rozliczenie z własną egzystencją. Porządek opowiadania w znacznym stopniu został przez niego uzgodniony z porządkiem fabularnym i poddany zabiegom retorycznym. Elementem retorycznej gry z odbiorcą jest już nienaturalność konstrukcji pierwszego zdania, przez użycie spójnika nacechowanego lekkim patosem i wyjaskrawiającego ból podmiotu. Wyznanie rozpoczyna bohater od określenia swojego stanu, by następnie przystąpić do zrelacjonowania niezwykłej „miłosnej przygody”, która w efekcie pogłębia alienację oraz poczucie pustki istnienia. Silne emocje zakłócają oczywiście rytm całości, sprawiają, że składnia rwie się - zwłaszcza w drugiej części tego ekspresjonistycznego poematu, gdy czas nakreślonych wydarzeń staje się niemal tożsamy z momentem snucia opowieści, a bohaterowi coraz trudniej odróżnić jawę od nękających umysł ułudnych wizji - jednak próba ułożenia zdarzeń w sekwencje, z uwzględnieniem ich chronologii, jest uderzająca, naturalnie przy zastrzeżeniu, iż rzeczywistym tematem monologu jest nie jedno czy drugie zdarzenie, lecz monologujące „ja”. Artykulacja wewnętrznego doświadczenia uporządkowana pod kątem odbiorcy nie oznacza bynajmniej, że ów odbiorca istnieje. Wręcz przeciwnie - wyznanie trafia w próżnię. Spotyka się z absolutnym milczeniem. Nieme pozostają także gwiazdy, do których bohater kilkakrotnie kieruje swe wezwania. W rezultacie osamotniony człowiek, którego skarga nie znajduje rezonansu ani wśród ludzi, ani w bezmiarze wszechświata - może jedynie zakończyć opowieść bezsilnym: „Jak cicho...” (s. 62).

Kim jest podmiot szukający zrozumienia dla swej sytuacji? Paradoksalnie - wiadomo o nim niewiele i niemało zarazem. Z jednej strony, nie jest znane nawet jego imię czy pochodzenie, a rozmyciu konkretu sprzyja silna liryzacja i metaforyzacja opowieści, nasuwającej skojarzenia z orientalną baśnią i powiązanej z mitem 
orfejskim. Z drugiej jednak, wnętrze bohatera zostaje na wskroś obnażone, świat przedstawiony jest bowiem de facto obrazem jego psychiki. W autodefinicji, opartej na anaforze i paralelizmie składniowym, mówiący przedstawia siebie jako więźnia przykutego do ściany w zatęchłych lochach, nigdy nie widzącego słońca i jedynie późnym wieczorem wypędzanego $\mathrm{w}$ kajdanach na powietrze w gronie innych dzielących ten sam los więźniów. Poczucie osaczenia bohatera buduje Miciński piętrowo. Zniewolenie mężczyzny nie zostało zredukowane wyłącznie do okoliczności wtrącenia go do ciemnicy i spętania łańcuchami. Stosując technikę „od szczegółu do ogółu”, przenosi uwagę czytelnika z pojedynczego lochu na scenerię wokół kazamatów, na których dziedzińcu niewolnicy spędzają początek każdej nocy otoczeni wieżycami strażnic i murem $\mathrm{z}$ wysokich skał. A poza tymi barierami, wzniesionymi siłami człowieka, czeka już cały bezmiar osaczenia i osamotnienia niemożliwy nawet do ogarnięcia okiem: pozbawiona życia skalista pustynia oraz przestwór morza. $Z$ tego żywota-więzienia nie sposób się wydostać. Toteż położenie spycha bohatera poematu na najniższy poziom bytu, czyni zeń istotę wyniszczoną, bliższą widmu niż człowiekowi; sprawia, że jest on „przegniły”, „zatruty”, „lichszy od pająków”, „skąpą jałmużną księżycowych promieni jak upiór karmiony" (s. 47). Implikuje poczucie pustki i absurdu egzystencji poddanej delimitacji tak w wymiarze somatycznym, jak epistemologicznym, choć toczącej się przecież, jak zauważa narrator, w otwartym obszarze niewyczerpanych potencji - „na bezgranicznym świecie”, pod „bezkresnymi przestworzami” nieba (s. 47 i 48, podkr. K.B.).

Zarysowane na wstępie elementy świata przedstawionego zawdzięczają wiele, jak widać, obrazowaniu gnostyckiemu. Rzeczywistość staje się dla doznającego podmiotu układem niekończących się antynomii, obejmujących wszystkie kategorie istnienia: mrok - jasność, sfera ziemska (i podziemna) - sfera astralna, zniewolenie - wolność, granice - bezkres, zamknięcie - otwarcie, małość człowieka - ogrom kosmosu. Bohater doświadcza rozdarcia świata, który nie stanowi harmonijnej jedności, lecz zawiera pierwiastki sprzeczne, stanowiące o nieustannym, nieznajdującym rozwiązania napięciu. Na nim samym również ciąży skaza niekompletności, wynikająca z niemożności zaspokojenia braku, osiągnięcia pełni istnienia, zintegrowania „ja”. Towarzyszy mu poczucie obcości, będące doznawaniem oddalenia od istoty życia, od prawdziwego świata ${ }^{10}$. Pozostaje on w fazie entropii, marząc o zapełnieniu pustki, wykroczeniu poza wyznaczony los i przeniknięciu sfery ducha, o uformowaniu ,jednostkowej, świadomej siebie odrębności”"1, co przekracza już ramy gnozy, a przynależy psychologii głębi. Sugestywnym wyrazem owych duchowych tęsknot są odbywające się na poziomie nieświadomości

10 Zob. H. Jonas, Religia gnozy, przeł. M. Klimowicz, Wydawnictwo Platan, Kraków 1994, s. 64-82.

11 J. Prokop, Żywioł wyzwolony. Studium o poezji Tadeusza Micińskiego, Wydawnictwo Literackie, Kraków 1978, s. 222. 
rojenia o sferze niebios, podczas których bohater - utraciwszy kontakt z rzeczywistością - pozostaje głuchy na wezwanie strażniczej trąbki.

Niemal całkowita ciemność, w której znajduje się bohater („leżałem w pomroce”), odnosi się tak do obszaru kazamatów, jak do jego własnej psychiki owładniętej przez mroki nieświadomego. Nietrudno się domyślić, że mamy w poemacie do czynienia z pejzażem wewnętrznym, „topografią świata imaginowanego”12, a cała opowieść to relacja z „przeżycia duchowego”, nabierająca znamion projekcji głębokich pragnień. Podobne rozwiązania pojawiały się w twórczości Micińskiego wielokrotnie, na co zwracał uwagę już Jan Prokop: „Miciński odkrywa nieprzeźroczystość własnego wnętrza i dlatego jawi mu się ono jako przestrzeń zewnętrzna. Zawartość psyche «wyprojektowana» jest w zewnętrzny obraz przestrzeni" ${ }^{\text {”3 }}$. W zbudowanym na antynomiach świecie przedstawionym jedna opozycja ulega zatem zatarciu: immanentne interferuje z zewnętrznym, dając mentalny krajobraz osamotnienia, zagubienia, osaczenia, tworzony nie tylko przez zamknięte wnętrza lochu, ale i otwarte, lecz wrogie przez swą rozległość obszary rozciągające się poza murami kazamatów.

Spętany w głębi lochów zbudowanych na skalnych wykrotach, skazany na nieustającą ciemność poniżej niedoścignionego poziomu gwiazd, trwa bohater w egzystencjalnej otchłani, w nicości bytu, w stanie przypominającym śmierć za życia. Tkwi gdzieś w podziemiach istnienia, uwikłany w mrok własnego wnętrza. Pozostaje na etapie katabazy, rozumianej jako próba penetracji własnej osobowości, jako spotkanie z tym, co nieświadome. Jest to więc katabaza w jej wzorcu Nervalowskim ${ }^{14}$. Od momentu rozpoznania obecności tego toposu wyrazistości nabiera wpisany w Pieśń tryumfującej miłości schemat mitu orfejskiego, potraktowany jednak à rebours, na miarę doświadczeń schyłku XIX wieku. Bezimienny bohater poematu to Orfeusz przetransponowany w czasy współczesne. Sytuacja jego zniewolenia w obszarze ciemności stanowi odpowiednik zstąpienia do Hadesu, jest zejściem w egzystencjalne czeluści, w piekło wewnętrzne, będące jednakowoż miejscem wtajemniczenia.

Podobnie jak tracki śpiewak - pogrąża się on w mroku (istotna wydaje się w tym kontekście etymologia imienia mitycznego lirnika wywodzona z greckiego słowa orphne, czyli mrok właśnie $\left.{ }^{15}\right)$, który umożliwia dotarcie do gnoseolo-

12 W. Gutowski, W mroku gwiazd. Poemat metafizycznego protestu i rozpaczliwej nadziei, w: tenże, Wprowadzenie do Xięgi Tajemnej. Studia o twórczości Tadeusza Micińskiego, Akademia Bydgoska im. Kazimierza Wielkiego, Bydgoszcz 2002, s. 208.

13 J. Prokop, dz. cyt., s. 224.

14 Zob. więcej w interesującym opracowaniu Magdaleny Siwiec Orfeusz romantyków. Mit o Orfeuszu w twórczości Juliusza Słowackiego i Gérarda de Nerval w kontekście epoki, Universitas, Kraków 2002.

15 Zob. A. Krokiewicz, Studia orfickie, w: tenże, Studia orfickie. Moralność Homera i etyka Hezjoda, Alethia, Warszawa 2000, s. 65. Badacz wskazał w swym studium także inne, mniej chętnie przyjmowane przez uczonych, skojarzenia etymologiczne dotyczące imienia „Orfeusz”. 
gicznej, metafizycznej i egzystencjalnej tajemnicy. Ciemność czyni jednostkę podobną ślepcowi - tak zresztą określa siebie na wstępie bohater poematu - lecz wyostrza jej widzenie wewnętrzne ${ }^{16}$. Noc rozmywa kontury tego, co znane, burzy racjonalny obraz rzeczy, otwierając na inny wymiar poznania. Podczas jej trwania człowiek zdolny jest przeniknąć najskrytsze głębie istnienia ${ }^{17}$. Leży ona u podstaw mitu genezyjskiego, istniała bowiem przed stworzeniem słońca i księżyca. Ten aspekt silnie eksponowały kosmogonie orfickie, uznające Noc za bóstwo, z którego powstały wszystkie inne, za arché, praprzyczynę i źródło całego wszechświata, co znalazło odzwierciedlenie w jednym z osiemdziesięciu siedmiu zachowanych do naszych czasów hymnów orfickich, napisanych rzekomo przez Orfeusza i należących do kategorii teletai, czyli wtajemniczeń, oraz wykorzystywanych - jak sądzą badacze - w charakterze pieśni podczas praktyki kultowej. Zgodnie z jego słowami, modlący się oddawali nocy cześć jako „rodzicielce tak bogów, jak ludzi” oraz „macierzy wszystkiego”"18. Ważna zarówno dla orfików, jak i dla sensów omawianego poematu jest antynomiczność nocy: niesie ona grozę swą czernią i wiąże z podziemnym światem umarłych, a jednocześnie zawiera aspekt niebiański, uraniczny, ponieważ jedynie w mroku, na nocnym niebie, widoczne są gwiazdy ${ }^{19}$. Toteż w poemacie katabaza motywuje swe przeciwieństwo - anabazę; ma być niezbędnym wstępem, krokiem na drodze do transgresji, integracji „ja”, finalnej pełni, etapem inicjacji służącej połączeniu $\mathrm{z}$ absolutem ${ }^{20}$. Preludium owej anabazy - której najistotniejszym elementem będzie spotkanie z księżniczką-Eurydyką - stanowi imaginacyjny wzlot ku niebiosom jako wyraz poczucia niespełnienia i tęsknoty. Widzialny firmament jest dla mężczyzny znakiem istnienia wspanialszej rzeczywistości i wartego spenetrowania obszaru tajemnic, daje złudzenie lepszego świata, ale jednocześnie swą niedostępnością urąga ludzkiemu nieszczęściu. Dlatego na widok konstelacji zawieszonej na sklepieniu niebieskim tuż nad jego głową, bohater stwierdza: „siedem gwiazd koronowało moje czoło niewolnika" (s. 49), co jest zarazem pierwszym sygnałem chrystusowych rysów postaci.

16 O znaczeniu motywu ślepoty pisałam w artykule „Bo mi się wciąż zdaje, gdy spojrzy na mnie, że widzi... nawet lepiej od innych... Że mnie do dna przeziera.... Symboliczne znaczenie ślepoty w dramacie młodopolskim, w: Jacek Malczewski i symboliści, red. K. Stępnik, M. Gabryś-Sławińska, Wydawnictwo Uniwersytetu Marii Skłodowskiej-Curie, Lublin 2012, s. 317-333.

17 Zob. hasło Noc, w: M. Lurker, Słownik obrazów i symboli biblijnych, przeł. bp K. Romaniuk, Wydawnictwo Pallotinum, Poznań 1989, s. 136-137.

18 [Hymn] Nocy. Kadzidło z pochodni, w: Hymny orfickie, przekł. i oprac. E. Żybert, Oficyna Wydawnicza Atut, Wrocław 2012, s. 61.

19 Zob. Komentarz, w: Hymny orfickie, s. 116, przypisy 88 i 92.

20 Pionierskich interpretacji motywu schodzenia w głąb dokonała M. Podraza-Kwiatkowska w książce Symbolizm i symbolika w poezji Młodej Polski, Wydawnictwo Literackie, Kraków 2001, zwł. s. 170-176. 
To ważne, że bohater dostrzega nad sobą właśnie Warkocz Bereniki, związana $z$ nim legenda aluzyjnie antycypuje bowiem rodzaj cierpienia, o jakie przyprawi mężczyznę wspinaczka na skałę podjęta w nadziei potwierdzenia związku z makrokosmosem. Gwiazdozbiór powstał przecież z miłości - to przeniesione na nieboskłon włosy żyjącej w III w. p.n.e. królowej Egiptu, która ścięła je i złożyła w ofierze za szczęśliwy powrót $\mathrm{z}$ wojny ukochanego męża Ptolemeusza III. Dodatkowo korona z siedmiu gwiazd nasuwa skojarzenia z Koroną Północną, która dla Greków była umieszczonym na niebie złotym diademem, jaki podarował Ariadnie jej niechciany mąż Dionizos. Powstały ok. trzech tysięcy lat temu mit o córce kreteńskiego króla, która zmarła na Naksos ze złamanym przez Tezeusza sercem, uważany jest za pierwszą literacko opracowaną historię tragicznej miłości, jaka przytrafia się i bohaterowi poematu Micińskiego. Czy jednak wspomniana w opowieści liczba gwiazd ma istotnie ważkie dla interpretacji poematu znaczenie? Wiadomo, że autor Nietoty wielokrotnie czynił siódemkę komponentem semantycznym i kompozycyjnym swych utworów (vide m.in. siedem cykli tomu $W$ mroku gwiazd), a mimo to trudno udzielić odpowiedzi na powyższe pytanie - także, a może przede wszystkim, ze względu na bogatą symbolikę tej liczby. Uwzględniając orfejski szyfr poematu, można przypomnieć, że Orfeusz uchodzi za konstruktora siedmiostrunowej liry, która wydawała doskonałe dźwięki odpowiadające harmonii siedmiu planet. Uważano go bowiem za pierwszego w Grecji znawcę zasad astrologii, przenikającego arkana niebios dzięki wiedzy o położeniu ciał niebieskich ${ }^{21}$. Znajomość nieboskłonu cechuje również narratora, który próbuje dosięgnąć tajemnic firmamentu poprzez fizyczne się doń zbliżenie, poprzez dosłowną wspinaczkę ad astra.

Zatem i Orfeusz, i bohater Pieśni tryumfującej miłości sięgają granicy świata dostępnego człowiekowi, pukają do bram nieznanego. Pierwszy schodzi do Erebu, drugi z podziemi bytu pnie się ku empireum - ze świadomością, że to wysiłek przekraczający możliwości ludzkiej kondycji, że nie sposób zdobyć pionowej skały stojącej w północnym narożniku więziennego podwórza. I rzeczywiście - wspinaczka po wąskich zrębach zostaje zahamowana na jakiejś skalnej przeszkodzie. A następnie w cudowny sposób wznowiona:

21 Zob. C. Rowiński, Orfeusz i Eurydyka, w: Mit - człowiek - literatura. Praca zbiorowa, red. S. Stabryła, Wydawnictwo Naukowe PWN, Warszawa 1992, s. 107, 117. W charakterze ciekawostkowego appendiksu można wspomnieć o jeszcze jednym siódemkowym aspekcie losów Orfeusza: według Georgik Wergilego tracki śpiewak przez siedem miesięcy płakał u źródła Strymonu po tym, jak Eurydyka pozostała w głębinach Hadesu. Ważną funkcję pełni siódemka w kosmologii gnostyckiej, jest to bowiem liczba sfer rozciągających się wokół Ziemi i zamykających człowieka niczym w więzieniu oddzielającym od Boga. Podobnie duch człowieczy (pneuma) zniewolony jest przez siedem szat duszy. 
[...] po zrębach wąziutkich piąłem się coraz wyżej - aż naglem uderzył głową o wykrot...

Kres tu mojej wędrówki ku gwiazdom...

Z rozpaczą przycisnąłem się do zimnej skały, jakby próbując rozeprzeć ją swoją tęsknotą -

A wtem stała się rzecz boska.

Srebrzysta melodia rozperliła się - niby słowiki w noc majową - z tajemniczych oddali płynie gondola cudownej brylantowej pieśni.

[...] nigdy potężniej huragan miłości nie uderzył w pierś niewolnika -

Wyciągnąłem ręce - i chwyciwszy jakąś wizję oparcia - rozkołysałem ciało swoje i ogromnym kręgiem je zatoczywszy - przerzuciłam w górę i czepiając się biegłem po skalistych zrębach jak łasica aż na szczyt (s. 49).

To ważny moment poematu. Nie tylko dlatego, że rozpoczyna on kluczową dla sensów utworu transgresję bohatera. Również z tego powodu, iż uprzytamnia, co jest owego doświadczenia katalizatorem. Nadludzka siła więźnia ma oto swe źródło w potędze muzyki, która - podobnie jak w micie orfejskim - posiada właściwości magiczne, silnie oddziałuje na otoczenie, łamie bariery, prowadzi poza granice widomego świata, porywa duszę, budząc w słuchaczu miłość. Narrator utworu zdradza wyraźne trudności z rozpoznaniem zagadkowej, trudno uchwytnej natury korelacji miłości i muzyki, urastających do rangi sił sprawczych procesu poznania. Charakter całego zajścia - rozlegającej się niespodzianie pieśni, która wywołuje miłosny malstrom, oraz fenomenu nagłej nadludzkiej siły - potrafi zamknąć jedynie w ramach formuły „stała się rzecz boska”, a konstatacja ta, będąca mglistą werbalizacją olśnienia, jest niewątpliwie i wyrazem przekonania o niebiańsko-boskim pochodzeniu muzyki. Moc melodyjnych tonów potężnieje, gdy stanowią one ekspresję namiętności. Wiedział o tym Orfeusz, próbując wybłagać u Hadesa uwolnienie Eurydyki. Miciński w intrygujący sposób odwraca sytuację mityczną: czarowne dźwięki, pozwalające bohaterowi-Orfeuszowi przekroczyć ograniczenia jego własnej kondycji i kontynuować inicjację, wydobywają się spod palców grającej na harfie ${ }^{22}$ księżniczki (Eurydyki), którą bohater widzi stojącą na

22 Orfeusza przedstawiano najczęściej z kitarą bądź lirą; harfa natomiast w kulturze starożytnej Grecji była instrumentem rzadszym i przeznaczonym głównie dla kobiet. Miciński mógł wybrać harfę jako instrument utożsamiany z mistyczną drabiną do nieba, przerzucający most między światami ziemskim i niebiańskim, a także łagodzący tęsknotę i melancholię (taką moc miała harfa króla Dawida, proroka). Nie bez znaczenia wydaje się również inspiracja słynnym tryptykiem Ogród rozkoszy ziemskich, który mógł pisarz widzieć w Madrycie, a w którego prawym skrzydle namalował Hieronim Bosch ludzkie ciało rozpięte w kształt krzyża na strunach olbrzymiej harfy i cierpiące piekielne męki. Zdaniem Cirlota, na obrazie Boscha „harfa mogłaby [...] symbolizować bolesne, krzyżowe rozpięcie człowieka między dążeniem do świata nadprzyrodzonego 
tarasie otoczonego ogrodem Alkazaru, jaki autor Nietoty oglądał zapewne podczas pobytu w Hiszpanii, być może w Granadzie lub Sewilli ${ }^{23}$. W proponowanej przez Micińskiego wersji à rebours to Orfeusz jest więźniem podziemnej krainy mroku, wyprowadzanym ku życiu (znakiem jego piękna jest przepych pałacu i jego otoczenia: cyprysy przypominające koronki, eukaliptusy niczym srebrne anioły, palmy o liściach imitujących strusie pióra, kaktusy naprężone jak węże zasłuchane we flet zaklinacza, rodyjskie marmury, posadzka rzeźbiona w złote arabeski) potęgą muzyki tworzonej przez kochającą kobietę.

Wyciągnęła ręce na spotkanie -

Oczy nasze stopiły się w jedno słońce upojenia - a z palców jej wybiegła skrzydlata wiekuista - święta - niewysłowiona - pieśń tryumfującej miłości (s. 50).

Uczucie wzbudzone pieśnią ma wymiar androgyniczny. Podmiot akcentuje jedność z ukochaną, w stanie utożsamienia upatrując objawienia absolutu: „Ja - Ty - i dusza nasza - Trójca nierozdzielna [...] - Adonai!...” (s. 50). Miłosną pełnię, o której pisał w słynnych dialogach Platon, transponuje Miciński w sferę sacrum, widząc w niej odbicie pełni i harmonii właściwych istocie boskiej, w sposób doskonały ucieleśniającej ideę wielości w jedności (Trójca Święta). Pamiętać jednak należy i o tradycji wcześniejszej. To pierwsi orficy, stawiając Erosa w panteonie najwyższych bóstw, uprzytomnili bowiem Grekom potęgę miłości przekraczającej ramy indywidualnego bytu, pozwalającej ludziom stworzyć doskonalszą od każdego z nich całość, wzbogacić jaźń dzięki drugiej oddanej im jaźni, a przez to wstąpić na prawdziwą drogę szczęścia i swobody ${ }^{24}$. Idea miłości stanowiła istotny

a miłością, skutkiem czego całe jego ziemskie życie jest oczekiwaniem". Ta interpretacja zadziwiająco dobrze wpisuje się w kontekst poematu (Harfa [hasło], w: J.E. Cirlot, Słownik symboli, przeł. I. Kania, Znak, Kraków 2006, s. 156; zob. też Harfa [hasło], w: Władysław Kopaliński, Słownik symboli, Wiedza Powszechna, Warszawa 1991, s. 108-109). Warto zaznaczyć, że harfa pojawia się stosunkowo często w poezji Micińskiego, m.in. w lirykach ***[Kwiat purpurowy marznie w lodowni...], ${ }^{* * *}\left[J a m\right.$ ciemny jest wśród wichrów płomień boży...], ${ }^{* * *}[\mathrm{Na}$ księżycu czarnym wiszę...], Baśń, Głębiny duch, Zamek duszy, Msza żałobna, Reinkarnacja, Serenada, Droga Mleczna.

Por. Alkazar przedstawiony przez Przybyszewskiego - który razem z Micińskim był w Hiszpanii na zaproszenie Wincentego Lutosławskiego - w poemacie Androgyne z 1899 roku (wyd. os. 1900). Na temat pobytu Micińskiego w Hiszpanii zob. m.in. S. Pigoń, Niesamowite spotkanie literackie. Tadeusz Miciński - Wincenty Lutosławski, w: tenże, Miłe życia drobiazgi, Warszawa 1964; J. Illg, Niesamowitego spotkania karty nieznane. Korespondencja Tadeusza Micińskiego z Wincentym Lutosławskim, w: Studia o Tadeuszu Micińskim, M. Podraza-Kwiatkowska, Wydawnictwo Literackie, Kraków 1979, s. 341-402; P. Sobolczyk, Tadeusza Micińskiego podróż do Hiszpanii, Wydawnictwo Adam Marszałek, Toruń 2005.

24 Zob. A. Krokiewicz, dz. cyt., s. 50-52. Według kosmogonii orfickiej Eros wylągł się ze srebrnego jaja, które złożyła Noc. To on miał wprawić w ruch cały wszechświat (zob. m.in. 
rdzeń ich doktryny ${ }^{25}$. Zapewne dlatego tak chętnie zarówno do orfejskiego mitu, jak i do filozofii starożytnych orfików nawiązywali romantycy. Miciński u samego kresu XIX wieku splata tradycję orficką z refleksją na temat przestrzeni wewnętrznej człowieka, w której dosięga on swej istotności - stąd w wypowiedzi narratora poematu mowa o duszy jako elemencie spajającym „ja” z „ty”, wspólnym dla pierwiastka męskiego i kobiecego. Stojąca na tarasie Alkazaru kobieta jest obrazem duszy bohatera - pochodzącą z najgłębszych warstw jego nieświadomości animą (łac. dusza), z którą konfrontacja stanowi niezbędny krok na drodze indywiduacji $^{26}$. Świadczy o tym również intrygująca „wertykalna” strategia: bohater musi podjąć trud anabazy, by ostatecznie z wysokiego szczytu ujrzeć księżniczkę daleko w dole („a w dole głęboko u stóp moich - maurytański ogród”, s. 49) - w głębinie własnej psyche.

Rozbudzona siła uczucia generuje wyrażoną $\mathrm{w}$ formie symbolicznych obrazów przemianę - kolejną fazę wyniesienia, które w intymnym doświadczeniu bohatera oscyluje na granicy projektowanego planu-marzenia i realności. Z ukochaną u boku, jak Orfeusz przekracza wszystkie formy materii, pokonuje siły natury, wznosi się ponad to, co istnieje fizycznie, przemieszcza się ponad czasem i przestrzenią, poza granicą świata. Wzlatuje, pozostawiając w dole wszelkie uraniczne modele, wyzwalając się spod ich wpływu i tym samym rzucając wyzwanie Demiurgowi:

Z bezmierną miłością trzymając ją w objęciach leciałem jak Demon ponad wszechświatami -

Jak Demon, którego niegdyś jedna kropla bólu mogła roztopić żelazo - a spojrzenie rezygnacji, rzucone w niebiosa, zatruwało je na wieki świętym wybrańcom i aniołom teraz - roztopiony w szczęściu - jako obłok w zorzy porannej - cichy - jako sen kwiatów lub muzyka gwiazd - radosny - jako zwiastowanie słońca w noc polarną - płynąłem w krainy marzeń, jakich nie ma na ziemi - (s. 51).

Oksymoroniczne sensy, za pomocą których podmiot próbuje wyartykułować swój stan szczęścia, bez wątpienia korespondują z powiązaną z androgynią ideą coincidentia oppositorum. Co ważne jednak, bohater pozostaje na poziomie porównań językowych oddających niewyobrażalność i skalę doznań; nie zyskuje

R. Graves, Mity greckie, przeł. H. Krzeczkowski, Państwowy Instytut Wydawniczy, Warszawa 1974, s. 46).

25 Obok idei związku wielości z jednością oraz idei nieśmiertelności dusz ludzkich.

26 Personifikacje animy pojawiają się w twórczości Micińskiego częściej - zwracali na ich obecność uwagę J. Prokop, dz. cyt., s. 156 oraz W. Gutowski we wstępie do Wyboru poezji z 1999 r., przedrukowanym następnie w zbiorze poświęconych Micińskiemu rozpraw Wprowadzenie do Xięgi Tajemnej, dz. cyt., s. 220. 
bliskiego panteizmowi przekonania o stopieniu elementów wszechbytu w jedność. Nie integruje się z całością istnienia, lecz dystansuje odeń, szybując „ponad”. Powrót do średniowiecznego modelu uniwersum nie jest możliwy. Miłość nie scala kosmosu, którego heterogeniczność i rozpad są faktem (wielość wszechświatów, na którą wskazuje narrator), inicjuje natomiast penetrację i integrację wielowarstwowego „ja” w procesie konfrontacji z nieświadomością. Marzenie o jedności, będące sensem orfizmu ${ }^{27}$, przenosi zatem Miciński w duchu fin de siècle’u na poziom jednostki i jej świata wewnętrznego. Dlatego komponentem pełni jest „dusza nasza”, nie zaś dusza (wszech)świata, a między tymi kategoriami w epoce intensywnych badań psychologicznych nie można już stawiać znaku równości. Nie zmienia to faktu, że miłość pozostaje w poemacie zasadą kosmiczną powiązaną z prawem harmonii, ta zaś przynależy do pola semantycznego związanego z muzyką. Wypada więc ponownie odwołać się do mitu, w którym harmonia Orfeuszowej pieśni odzwierciedlała harmonię świata, a nieco później posłużyła pitagorejczykom do opracowania koncepcji muzyki sfer, czyli muzyki płynącej z samego kosmosu, będącego źródłem najpiękniejszych tonów i doskonale zestrojonych dźwięków.

Skąd bowiem pochodzi właściwie pieśń słyszana przez bohatera? Z opowieści wynika, że wydobywa się ona spod palców księżniczki Alkazaru trzymającej w dłoniach harfę. Brak w utworze wzmianki o tym, jakoby księżniczka śpiewała, wręcz przeciwnie - podkreśla się jej milczenie; rozlega się zatem „pieśń bez słów”, zawierająca treści immanentne, a więc niepotrzebująca medium werbalnego. W przeciwieństwie do wyrażeń językowych służących reprezentacji sfery fenomenów, muzyka - jak twierdził Schopenhauer - jest bezpośrednią ekspresją woli, odzwierciedla sedno podmiotu i zjawisk, czystą prawdę o nich ${ }^{28}$. Bohater ulega jej czarowi, ponieważ jest ona uczuciem per se, siłą kierującą człowiekiem na równi

27 Tajemniczy związek wielości z jednością rozpatrywali orficy przede wszystkim na poziomie metafizyki, podkreślając związek teogonii z kosmogonią. Zwracali uwagę, że wielość wyłania się z jedności, ale po pewnym czasie do niej powraca a wszystkie rzeczy są tożsame. $\mathrm{Na}$ poziomie uczuć czynnikiem jednoczącym jest miłość i harmonia części tworzących całość. Ucieleśnienie marzeń o powrocie do pierwotnej jedni stanowi postać Orfeusza, który połączył różne wymiary istnienia poprzez zstąpienie do piekieł, a dzięki sile muzyki integruje wszelkie byty: bogów, ludzi, zwierzęta, rośliny. Dlatego w wierzeniach orfickich panuje zasada pojednania i zgody nie tylko między ludźmi, ale także między ludźmi a pozostałymi elementami świata (zob. A. Krokiewicz, dz. cyt., s. 41, 49; M. Siwiec, dz. cyt., s. 13).

28 A. Schopenhauer, Świat jako wola i przedstawienie, przeł. J. Garewicz, t. 1-2, Wydawnictwo Naukowe PWN, Warszawa 2009 (tu zwłaszcza: t. 1 - par. 52 w księdze trzeciej; t. 2 - rozdz. 39 pt. Przyczynek do metafizyki muzyki). Na gruncie polskim Przybyszewski argumentował, iż muzyka jest doskonalsza od pozostałych dziedzin sztuki ze względu na najszersze możliwości ekspresji: „dla wszystkiego, co niepojęte [...], dla czego nie umieliśmy podać powodu, dla czego w mowie nie ma słowa, dla czego najbystrzejsze określenie jest tylko sztuczką karcianą, dla tego mamy w dźwiękach wyraz" (Z psychologii jednostki twórczej. Chopin 
z popędami i emocjami, które są składową woli; oddziałuje na najgłębsze doznania, ponieważ zostaje przez duszę całkowicie zrozumiana. Myśl niemieckiego filozofa - która reformatorom pokroju Wagnera pozwoliła widzieć w muzyce narzędzie katharsis, środek bezpośredniego odwoływania się do woli człowieka i poruszania jego istoty ${ }^{29}$ - Miciński nasyca treściami metafizycznymi i psychologicznymi. Pieśń jest w poemacie nie tylko, jak mówi bohater, „niewysłowiona” (s. 50), lecz także - boska, a zatem powiązana z transcendencją i wyższym porządkiem.

Właściwa muzyka sfer pojawia się jako analogia dla stanu wewnętrznego podmiotu w szczytowym momencie anabazy. Istotne, że rozbrzmiewa ona nie w Kosmosie, lecz w narratorze, który szybuje ponad wszechświatami szczęśliwy i cichy niczym „muzyka gwiazd”, odnalazłszy wewnętrzną harmonię (użyte porównanie świadczy o tym, że Miciński znał pitagorejską ideę przyjmującą, iż muzyka sfer pozostaje niesłyszalna dla człowieka - „cicha” - z powodu dostojeństwa i triumfalności dźwięków, do odbioru których ludzki aparat słuchowy nie został dostrojony). Melodia ma zatem źródło w bohaterze, i to od początku, skoro poruszająca struny instrumentu księżniczka jest obrazem jego duszy. Można pokusić się o dalsze wnioski: Eurydyka-księżniczka zostaje utożsamiona z muzyką. Bohater-Orfeusz ma jej miłość tylko w pieśni, i tylko gdy rozbrzmiewa pieśń, pobudzona zostaje kreacyjna moc jego wyobraźni, którą poświadcza słowami: „i tworzyłem światy wizyj - jakich nie było nigdy w raju -” (s. 51). Blanchot pięknie pisał w jednym z esejów: „Błąd Orfeusza zdaje się tkwić w pragnieniu widzenia i posiadania Eurydyki, podczas gdy jego jedynym przeznaczeniem jest pieśń”30. Ale nie ma pieśni bez Eurydyki a Eurydyki bez pieśni, obie konotują w utworze upragnioną przez bohatera harmonię, która w świecie Greków znaczyła etymologicznie tyle, co zestrój, zjednoczenie, integralność składników, jako bogini patronowała zaś prawdziwej miłości. W poemacie Micińskiego sprzężenie zasłyszanych dźwięków z narodzinami uczucia ma więc charakter wielopłaszczyznowy i synkretyczny. Wyrazem łączenia różnorodnych tradycji jest wprowadzenie do poematu hebrajskiego imienia księżniczki - Miriam. Mało prawdopodobne, by Miciński zastosował je ze względu na znaczenie („być piękną”) i pokrewieństwo z egipskim słowem mer, tj. miłość, bowiem jego etymologia jest niepewna i budzi wątpliwości. Przypuszczalnie pisarz pragnął skierować uwagę czytelnika na starotestamentowy epizod, w którym siostra Mojżesza - ogarnięta duchem Bożym - śpiewa triumfalną pieśń

i Nietzsche, tłum. S. Helsztyński, w: tenże, Wybór pism, oprac. R. Taborski, Zakład Narodowy im. Ossolińskich, Wrocław 1966, s. 21).

29 A. Nowok, Nadczłowiek, dramat i katharsis. O filozoficzno-estetycznych aspektach reformy opery Ryszarda Wagnera, http://meakultura.pl/edukatornia/nadczlowiek-dramat-i-katharsis-o-filozoficznoestetycznych-aspektach-reformy-opery-ryszarda-wagnera-520 (dostęp: 10.10.2013).

30 M. Blanchot, Spojrzenie Orfeusza, przeł. M.P. Markowski, „Literatura na Świecie” 1996, nr 10, s. 37. 
chwały powodu przejścia Izraelitów przez Morze Czerwone. Egzegeci widzą w jej pieśni najstarszy dowód biblijny mówiący o wyjściu z Egiptu, a sama Miriam zyskuje ważną rolę w ucieczce „z domu niewoli”, w drodze ku wyzwoleniu, jakie ma stać się przecież i udziałem bohatera poematu.

Będący punktem wyjścia „duchowej przygody” model romantyczny, w którym kobiecie przypada rola cicerone, zostaje jednak przez pisarza odwrócony, podobnie jak sam mit o Orfeuszu. Iluzja niezwykłego wyniesienia i miłosnego spotkania pryska wraz z nadejściem świtu niczym czar w baśniach. Tylko noc jest porą kontemplacji, sprzyjającą próbie przeniknięcia tajemnic. Przed wschodem słońca bohater - spełniając nieme błagania księżniczki - zsuwa się w dół, w swą otchłań. Kolejna próba wdrapania się na szczyt w celu zyskania pewności, że spojrzenie ukochanej oraz doświadczenie bezkresu nie były wyłącznie sennym mirażem bądź halucynacją więźnia, już się nie powiedzie - zakończy bolesnym upadkiem ze skały i zakuciem w łańcuchy.

Od tego momentu dramatyzm przeżyć podmiotu ulega spotęgowaniu, choć na płaszczyźnie konstrukcyjnej utworu napięcie spada po kulminacyjnym momencie anabazy. Wrzuconemu do ciemnicy mężczyźnie pozostaje ponownie los niewolnika zawieszonego „nad bezdenną próżnią” bytu, ale już z dojmującą, przeklętą świadomością istnienia doskonalszej rzeczywistości i niedokończonej szansy wykroczenia poza ograniczenia „ja”.

Bohater miota się między marzeniem o jedności rozumianej ontycznie i psychologicznie a przeczuciem klęski tożsamej z unicestwieniem duchowym. Jego myśli się plączą, organizm drży z zimna, jednocześnie płonąc od gorączki. Mężczyzna balansuje na granicy lęku przed końcem i pragnienia śmierci, którą przyzywa w tonie dekadenckiej litanii. Pojawiają się u niego pokusy masochistyczne i wampiryczne jako objawy agresji wywołanej narastającą złością i bezsilnością. Ze stanu bliskiego szaleństwu, spotęgowanego jeszcze przekazaną przez strażników wiadomością o ślubie księżniczki, ponownie - jak mu się zdaje - wyrywa go pieśń, dodająca sił do zerwania kajdan i sforsowania krat. Wyswobodzenie się z celi kończy się jednak ostatecznym upadkiem w rozpościerające się $\mathrm{w}$ dole a niedostrzegalne urwisko - symbolicznie: w przepaść psychiczną. $\mathrm{W}$ omdleniu spowodowanym uderzeniem bohater doznaje halucynacji, w których przenosi się na teren Alkazaru, podpatruje księżniczkę w towarzystwie jej oblubieńca, a następnie słucha wygrywanej przez nią na harfie pieśni weselnej, „czarodziejskiej pieśni, gwiazdami przetykanej”, w której widzi tym razem „pieśn zbezczeszczonej miłości” (s. 60). Melodia, o której sądził, że jest kierowana do niego, przyprawia go teraz o niewyobrażalne katusze; miast wyzwalać jak w micie orfejskim - niszczy. Poszczególne dźwięki przypominają chińską torturę wodną:

[...] słucham przedziwnej melodii srebrzystych kropel, które spadają wciąż na jedno miejsce mego mózgu - 
naprzód jako płatki róż więdnących - potem - jako srebrzyste pieniążki - potem jako ciężkie gwoździe, którymi nabijają tarcze -

I wciąż rośnie ich moc - gradem sieką mnie i deszczem kamiennym - druzgocą mnie na wskroś [...]. (s. 6o-61)

W scenie spotkania bohatera z księżniczką eksponuje Miciński motyw spojrzenia, tak istotny w micie orfejskim, ale niebagatelny i dla literatury młodopolskiej, eksponującej performatywny charakter patrzenia, wskazującej na jego hipnotyczną, uwodzicielską, erotyczną moc. Kontakt wzrokowy zbliża, zadzierzga silną uczuciową więź. Czytamy o niej już u Platona. W Fajdrosie filozof pisze, jak to promieniująca uroda młodego chłopca uwalnia strumień drobinek, które pobudzają oczy miłującego i przenikają w głąb jego duszy. Łaskotana przez wizualne cząsteczki psyche wysyła w odpowiedzi strumień, który - niesiony przez promień wzrokowy - kieruje się ku ukochanemu obiektowi, wciska w jego oczy, dosięga duszy i ją rozpala. Eros jest zaraźliwy, a infekcja przenosi się przez wymianę spojrzeń $^{31}$. Wzrokowe porozumienie jest w poemacie Micińskiego, podobnie jak w greckiej koncepcji miłości, ważnym aspektem budowanej dwój-jedni (już w relacji z pierwszego kontaktu z księżniczką narrator akcentuje: „Oczy nasze stopiły się w jedno słońce upojenia” - s. 50), ale siła odrzuconego uczucia może sprawić, że wzrok pali, sprawia ból, zabija. Dlatego księżniczka łaskawie pozwala wynędzniałemu intruzowi wysłuchać ślubnej pieśni, ale jedynie po zawiązaniu mu oczu:

Nogi moje obrzękły - pierś zapadła się - ręce obwisły bezwładnie - i tylko w oczach skupia się moc - palą się - czuję wulkany, jakie z nich biją. Ona mimo woli odwróciła się w moją stronę - i krzyknęła przeraźliwie.

[...]

Boję się swego wzroku - i wbijam go w ziemię, bo wzrok szaleńca może zabijać $[\ldots]$

Spotkały się nasze wejrzenia i harfa z brzękiem upadła na marmury.

„Związać mu oczy” [...]. (s. 59-60)

Niepożądane spojrzenie, będące złamaniem zakazu, wygórowanym żądaniem, niemożliwą do przezwyciężenia pokusą, powiększa repertuar loci communes mitu orfejskiego oraz Pieśni tryumfującej miłości. Wyjście z piekła z (od)zyskaną Eurydyką nie udaje się ani bohaterowi mitu, ani powstałego prawie dwa i pół tysiąca lat później młodopolskiego poematu ${ }^{32}$, choć - zdawałoby się - jest nadzwyczaj bliskie,

31 F. Frontisi-Ducroux, Oko, wzrok, spojrzenie - kilka greckich wyobrażeń, przeł. W. Michera, „Konteksty” 2005, z. 3, s. 5-11.

32 O Orfeuszu wspomina po raz pierwszy w VI w. p.n.e. poeta Ibikos z Region. Tracki muzyk jest przedstawiony także na metopie z tego samego stulecia należącej do skarbca Sykiończyków 
niemal urzeczywistnione. Eurydyka jest przecież na wyciągnięcie ręki jako upragniony cel marzeń: Orfeusz, odwróciwszy się w kierunku ukochanej, traci ją na moment przed opuszczeniem Hadesu; nieszczęśliwy więzień, ośmieliwszy się pragnąć ujrzenia księżniczki, otrzymuje od jej dworaków cios w głowę w chwili, gdy - jak czuje - zarzuca mu ona ręce na szyję w geście duchowej doń przynależności.

I w mitologii, i u Micińskiego znajdujemy informacje o dalszych losach bohatera - osamotnionego, bolejącego nad stratą, pogrążonego w bezsilnej żałości. Bezimiennego więźnia czeka los banity na pustyni oraz poczucie wielkiego oszustwa, przekonanie, że „świata nie było i nie ma”, a jedyną rzeczywistością jest grzęzawisko, w które zapada jego „gnijąca dusza” (s. 61). O tak głębokiej rozpaczy poruszająco pisał w prywatnych notatkach Gustave Moreau, który mniej więcej w tym samym czasie, kiedy Miciński tworzył swój poemat, pracował nad płótnem Orfeusz na grobie Eurydyki:

Dusza jest sama, utraciła wszystko, co było jej wspaniałością, jej siłą, jej słodyczą, płacze sama nad sobą, w zupełnym opuszczeniu, w niepocieszonej samotności; jęczy i jej ciężka skarga jest jedynym ludzkim odgłosem w tej samotnej śmierci... ${ }^{33}$

Francuski symbolista dostrzegł w micie sens głębszy, wykraczający poza li tylko miłosną żałobę. Utratę, jakiej doświadczył Orfeusz, interpretował nie na płaszczyźnie tragedii uczuciowej, lecz w wymiarze osobowościowym. Odczytywał ją jako klęskę jednostki, której pozostaje pustka duszy. Podobny wydźwięk ma wersja Micińskiego.

Odnalezienie sensu „ja”, scalenie własnej podmiotowości i wyzwolenie z ontologicznych ograniczeń ku sferze transcendencji pozwalającej zharmonizować psychikę do stanu pełni, okazuje się wyłącznie rojeniem, mirażem spragnionego umysłu, imaginacyjną ułudą. Eurydyka, będąca w poemacie le double Orfeusza ${ }^{34}$, pozostaje niezintegrowaną cząstką jego osobowości, niespełnionym marzeniem o wykreowaniu indywidualnej jaźni, o samospełnieniu. Ekskursja poza granice dostępnego bohaterowi świata tylko przez chwilę ma znamiona przygody „ja”

w Delfach. Miłość Orfeusza i Eurydyki poświadczona jest już wyraźnie w Alkestis Eurypidesa, a więc w V w. p.n.e. Zob. m.in. M. Eliade, Historia wierzeń i idei religijnych, przeł. S. Tokarski, t. 2, Pax, Warszawa 2008, s. 151-152 oraz Z. Kubiak, Mitologia Greków i Rzymian, wyd. Il popr., Świat Książki, Warszawa 1998, s. 355.

33 Fragment tych niepublikowanych zapisków podaje M. Poprzęcka za: J. Paladilhe, Gustave Moreau, Paris 1971, s. 65. M. Poprzęcka, W stronę ukochanych cieni. Obraz Orfeusza w sztuce symbolizmu, w: Mit Orfeusza. Inspiracje i reinterpretacje w europejskiej tradycji artystycznej, red. S. Żerańska-Kominek, Wydawnictwo słowo/obraz terytoria, Gdańsk 2003, s. 234.

34 Ten inspirujący aspekt relacji kochanków eksplorował wcześniej Ballanche, którego Orfeuszowi poświęca uwagę w przywoływanej już pracy M. Siwiec (dz. cyt., s. 74-76, 133-134, 157-158 i in.). 
triumfującego. W istocie boleśnie uprzytamnia zniewolenie we własnym wnętrzu, niemożność przejścia z egzystencji-śmierci do egzystencji-życia, z piekła dezintegracji ku astralnej wolności (nad)boskich mocy. Co więcej, w rezultacie dotkliwej porażki owa doskonałość i majestatyczność stellatum podlega demistyfikacji. Celowość wszechświata zostaje podważona na równi z człowieczą zdolnością kreowania własnej podmiotowości. Gwiazdy, których widok motywuje do ekspansji psyche, „które mnie wzbijały - jak mówi bohater - ponad wszystkie szczyty mego więzienia" (s. 62), pozostają nieprzekraczalną granicą oddzielającą i od prawdy o „ja”, i od transcendencji: „znowu nad moją głową świecą” (s. 62). Trwają niewzruszenie, tak bezwzględne w swej constans, iż sprawiają wrażenie martwych. Ich światło zdaje się jedynie błądzącym w kosmosie echem pierwotnego blasku - budzącą nadzieję złudą, urągającą w istocie człowieczej przemijalności i metafizycznej tęsknocie. Owe gasnące gwiazdy ${ }^{35}$ tworzą firmament-falsyfikat maskujący pustkę nieba, unieważniający sens ludzkiego dążenia wzwyż, uświadamiający człowiekowi egzystencjalną nicość ${ }^{36}$ :

Kto wie? Może już od wieków zamarły -

i tylko upiory ich świateł błądzą po pustyniach -

kształtem złamanego krzyża urągające... (s. 62)

Nawet jeśli istnieje porządek transcendencji, to człowiek go nie rozpoznaje i nie jest jego częścią ${ }^{37}$. Harmonia wszechświata to iluzja, skoro stellatum jawi się jako cmentarzysko, przestrzeń upiorów zdestruowanego uniwersum, sfera nie tylko obca, ale i groźna, przysparzająca jednostce - z natury słabej i bezradnej wobec ogromu świata - bólu i cierpienia:

O gwiazdy!

Na waszych złotych ćwiekach krzyżujecie najbiedniejsze ze stworzeń -

bo już nie ma nic biedniejszego nad Pana wszechświatów - Syna bożego -

który kona - na krzyżu - gwiazd -

Jak cicho... (s. 62)

35 Ów astralistyczny symbol poezji Micińskiego analizował W. Gutowski w rozprawie „A gwiazdami osypuje Mrok..." O symbolice uranicznej w poezji Tadeusza Micińskiego, w: Poezja i astronomia, red. B. Burdziej, G. Halkiewicz-Sojak, Wydawnictwo Uniwersytetu Mikołaja Kopernika, Toruń 2006 s. 431 i nast. Praca ta została przedrukowana w najnowszej książce badacza pt. Między inicjacją a nicością. Studia i szkice o literaturze modernizmu, Bydgoszcz 2013.

36 Podobne refleksje na temat sfery astralnej znajdujemy i u innych młodopolskich poetów - poświęciła im uwagę A. Wydrycka w artykule Motywy gwiazd w liryce młodopolskiej, w: Poezja i astronomia, s. 403-421.

37 Por. uwagi W. Gutowskiego, „A gwiazdami osypuje Mrok...”, s. 428, przypis 18. 
Epilog anabazy podmiotu, konstatującego finalnie: „Ale te gwiazdy [...] znowu nad moją głową świecą”, sprawia wrażenie świadomej polemiki z Dantem, który po opuszczeniu zaświatów z ufnością spoglądał ku gwiazdom potwierdzającym ład świata i celowość pojedynczego istnienia w poincie każdej części Boskiej Komedii. Drugim celowo potraktowanym opacznie punktem odniesienia była zapewne dla Micińskiego słynna Kantowska formuła o „niebie gwiaździstym nade mną”. Zawieszony między dwiema otchłaniami: nieskończonością i nicością, mógłby raczej bohater poematu powtórzyć za Pascalem: „Wiekuista cisza tych nieskończonych przestrzeni przeraża mnie".

Wykorzystuje Miciński utrwalony w sztuce od wieków, a bliski myśli modernizmu za sprawą dzieła Nietzschego (ukończonego w 1889 roku, o czym świadczy datowanie na tytułowej stronie rękopisu, ale wydanego dopiero w roku $1908^{38}$ ) - motyw Ecce homo. Paralele między przeżyciami bohatera a Pasją - akcentowane właściwie od początku poematu - w finale nabierają wyrazistości, układają się w spójny interpretacyjnie obraz: otóż najpierw korona z gwiazd niczym korona cierniowa, później przebijający bohatera „ostry gwóźdź zwątpienia” (s. 52), poczucie bólu i osamotnienia wyrażone w formule „O Boże - Boże - czemuś mnie opuścił!...” (s. 55), wreszcie ukrzyżowanie na ćwiekach gwiazd. Bohater utworu byłby zatem Orfeuszem o Chrystusowych rysach - co ciekawe, nie po raz ostatni w twórczości Micińskiego. Cecylia Suszka podobieństwa do Nazarejczyka dostrzegła w Orfeuszu ze znacznie późniejszej, niedokończonej powieści Mené-Mené-Thekel Upharisim!... - wyszydzonym przez tłum, obrzuconym guzikami, z krwawiącymi rękami ${ }^{39}$.

Paralela Orfeusz-Jezus tylko pozornie może budzić niezgodę czy zdziwienie. W istocie bliska była już tradycji wczesnochrześcijańskiej. W trackim śpiewaku widziano prefigurację Bożego Syna, którego przedstawiano z atrybutami Orfeusza: z lirą i w otoczeniu zwierząt (obaj mieli dar ich poskramiania); takie wizerunki Orfeusza-Chrystusa jako natchnionego śpiewaka i „dobrego pasterza” były elementem np. malowideł katakumbowych ${ }^{40}$. Postać Orfeusza wzbogaciła więc symbolikę przedstawień ikonograficznych, ale odegrała również rolę znacznie poważniejszą: analogie między postaciami dotyczyły podobieństwa zjawienia się Orfeusza na wzgórzu w Tracji do transfiguracji na górze Tabor, roli rewela-

38 Wydanie polskie ukazało się w 1912 roku na podstawie wersji ocenzurowanej przez siostrę filozofa.

39 Zob. C. Suszka, W poszukiwaniu utraconej jedni. O synkretyzmie kulturowo-religijnym w twórczości Tadeusza Micińskiego, „Ruch Literacki” 2001, z. 2, s. 175. Być może inspirację stanowił dla Micińskiego Boski Orfeusz (El divino Orfeo, 1663) Pedra Calderóna de la Barca - alegoryczny dramat związany z liturgią święta Bożego Ciała, w którym Jezus ukryty jest pod postacią mitycznego lirnika.

40 A. Krokiewicz, dz. cyt., s. 30. Zob. też. D. Forstner, Świat symboliki chrześcijańskiej, przeł. i oprac. W. Zakrzewska, P. Pachciarek, R. Turzyński, Warszawa 1990, s. 340-341. 
tora prawd wiecznych, motywu zstąpienia do Piekieł, udziału w tajemnicy życia i śmierci, konania w umęczeniu ${ }^{41}$, a także wspólnych elementów kultu religijnego (ofiara, oczyszczenie, łaska) ${ }^{42}$. Wybitny znawca tematu, Adam Krokiewicz uważał, że wśród chrześcijan z dużym prawdopodobieństwem było wielu nawróconych orfików, a ich wierzenia oraz dawne poematy orfickie miały wpływ na powstawanie gnozy chrześcijańskiej ${ }^{43}$.

Paralela Orfeusz-Jezus ma w poemacie sens negatywny, odwrócony. W wersji zaproponowanej przez młodopolskiego autora ani Orfeusz, ani Chrystus nie są władni, by dokonać zjednoczenia przeciwieństw (przypomnijmy, że krzyż w symbolice wyraża ideę pojednania sprzeczności ${ }^{44}$ ), doprowadzić do - użyję adekwatnego w kontekście poematu, astronomicznego określenia - koniunkcji zasady duchowej i ziemskiej, wyjść z obszaru śmierci.

Miłości wzniosłej, majestatycznej, która mogłaby być fundamentem jedności i autowtajemniczenia, miłości-sacrum z orfejskiego mitu, przeciwstawiona zostaje w poemacie miłość-profanum, odrzucona, będąca skutkiem pomyłki, a więc skalana nieautentycznością, poniżająca kochającego. Miłość triumfującą zastępuje miłość zbezczeszczona. Toteż będąca jej wyrazem pieśń jest świętokradztwem, znieważeniem rewelatorskiej, objawieńczej, sakralnej istoty muzyki, w której sens - jak się zdaje - bohater nie zaprzestaje wierzyć. Trzykrotnie powtórzony przez niego w finale przysłówek „cicho” staje się implicytywnym odzwierciedleniem tęsknoty za transgresyjną mocą wtajemniczenia przez dźwięk otwierający wrota innego świata, bezsilną skargą Orfeusza tragicznie pogrążonego w milczeniu.

U Micińskiego pozostaje wyłącznie cisza pod bezlitosnym niebem, które uświadamia człowiekowi jego samotność i potęguje odczucie uwięzienia w świecie pozbawionym metafizycznego uzasadnienia. Protagonista jest tu człowieczym widmem lamentującym pod upiorami gwiazd, przygniatającymi jak kosmiczny los. Modernistyczna potrzeba wyrwania się z zagubienia i regresu, wydobycia z pustki, spirali cierpienia i egzystencjalnej ciemności do pełni życia podmiotowego, nie zostaje spełniona. Zdezintegrowany podmiot nie odnajdzie sensu w miłości-transcendencji, bo ta przybiera znamiona tęsknoty za niemożliwym. Istota bytu, a przede wszystkim istota „ja”, pozostaje ukryta „za zasłoną Sais”.

41 Według różnych wersji mitu Orfeusz miał zostać rozszarpany przez zazdrosne trackie kobiety, na które po utracie Eurydyki nie zwracał uwagi, bądź przez menady, które rozerwały go na strzępy na rozkaz Dionizosa po tym, jak Orfeusz odwrócił się od boga i przeciwstawił składanym mu krwawym ofiarom oraz orgiom. Inny wariant podaje, iż Orfeusz zginął od Zeusowego pioruna za ujawnienie tajemnic świata zmarłych.

42 O podobieństwach postaci Orfeusza i Jezusa zob. M. Siwiec, dz. cyt., s. 130-148 (rozdz. Religia).

43 A. Krokiewicz, dz. cyt., s. 30.

44 Zob. Krzyż [hasło], w: J.E. Cirlot, dz. cyt., s. 208-209 oraz Krzyż, Ukrzyżowanie [hasło], w: M. Lurker, dz. cyt., s. 101-103. 
Na zakończenie warto poruszyć kwestię ewentualnego związku Pieśni tryumfującej miłości z powstałą blisko dwadzieścia lat wcześniej, w roku 1881, nowelą Iwana Turgieniewa, noszącą dokładnie ten sam tytuł (Pesn' toržestvujuščej ljubvi). Badacze, zgadzając się, iż Miciński prawdopodobnie znał prozatorską perełkę rosyjskiego pisarza ${ }^{45}$, bezradnie rozkładają ręce, próbując odpowiedzieć na pytanie, czy autor Nietoty zamierzenie odniósł się utworu poprzednika - tak wiele dzieli ekspresjonistyczny poemat od małej prozy, inspirowanej włoskim renesansem. Jako oczywiste podobieństwo wskazać można bowiem jedynie temat: niespełnioną miłość, ten jednak był wspólny dla ogromnej ilości młodopolskich dzieł. Sądzić można, że inspiracje tkwią głębiej i że Miciński czytał Turgieniewa przez Nietzschego. Bohaterowie noweli reprezentują bowiem wyróżnione przez niemieckiego filozofa przeciwstawne pierwiastki: uprawiający malarstwo Mucjusz - apolliński, pasjonujący się muzyką Fabiusz - dionizyjski. Drugi z żywiołów wiąże się z dążeniem do metafizycznego poznania i mistycznego zjednoczenia ze światem, $\mathrm{z}$ wejrzeniem $\mathrm{w}$ istotę rzeczy, z uczestnictwem w doskonałości i pełni (prajedni), której gorąco pragnie i podmiot poematu Micińskiego. Co więcej, odsłania on antynomiczność rzeczywistości, zbudowanej - jak u autora Nietoty - na opozycjach, wśród których jedna z najbardziej ważkich dotyczy dwoistej, tytaniczno-boskiej natury człowie$\mathrm{ka}$, zajmującej istotne miejsce $\mathrm{w}$ ufundowanej ma micie dionizyjskim doktrynie orfickiej $^{46}$.

45 Zob. A. Semczuk, Iwan Turgieniew, Wiedza Powszechna, Warszawa 1970; W Gutowski, Komentarz edytorski, s. 302; W. Koschmal, Przeksztatcenie noweli w poemat prozq. „Pieśń tryumfującej miłości” I.S. Turgieniewa i T. Micińskiego, „Rocznik Komisji Historycznoliterackiej” 1990, t. XXVII, s. 171.

46 Przypomnijmy: Tytani rozszarpali i pożarli Zeusowego syna - małego Zagreusa, ale z uratowanego serca boskiego dziecka odrodził się drugi Zagreus, czyli Dionizos. Zeus spalił Tytanów piorunem, zaś z ich prochów stworzył rodzaj ludzki, który nosi w sobie element „tytaniczny”, zły, ale także pierwiastek boski z wchłoniętego przez Tytanów Zagreusa. Dlatego - jak uważali orficy - dobro walczy w człowieku ze złem, dusza z ciałem. 


\section{Bibliografia}

Blanchot Maurice, Spojrzenie Orfeusza, przeł. M.P. Markowski, „Literatura na Świecie” 1996, nr 10, s. 35-42.

Chylińska Teresa, Karol Szymanowski i Tadeusz Miciński, w: Studia o Tadeuszu Micińskim, red. M. Podraza-Kwiatkowska, Wydawnictwo Literackie, Kraków 1979, s. 325-340.

Cirlot Juan Eduardo, Słownik symboli, przeł. I. Kania, Znak, Kraków 2006.

Eliade Mircea, Historia wierzeń i idei religijnych, przeł. S. Tokarski, t. 2, Pax, Warszawa 2008.

Forstner Dorothea, Świat symboliki chrześcijańskiej, przeł. i oprac. W. Zakrzewska, P. Pachciarek, R. Turzyński, Pax, Warszawa 1990.

Frontisi-Ducroux Francoise, Oko, wzrok, spojrzenie - kilka greckich wyobrażeń, przeł. W. Michera, „Konteksty” 2005, z. 3, s. 5-11.

Gmys Marcin, Harmonie i dysonanse. Muzyka Młodej Polski wobec innych sztuk, Wydawnictwo Poznańskiego Towarzystwa Przyjaciół Nauk, Poznań 2012.

Graves Robert, Mity greckie, przeł. H. Krzeczkowski, Państwowy Instytut Wydawniczy, Warszawa 1974.

Gutowski Wojciech, „A gwiazdami osypuje Mrok...” O symbolice uranicznej w poezji Tadeusza Micińskiego, w: Wojciech Gutowski, Między inicjacją a nicością. Studia i szkice o literaturze modernizmu, Wydawnictwo Uniwersytetu Kazimierza Wielkiego, Bydgoszcz 2013, s. 298-315.

Gutowski Wojciech, Wprowadzenie do Xięgi Tajemnej. Studia o Twórczości Tadeusza Micińskiego, Akademia Bydgoska im. Kazimierza Wielkiego, Bydgoszcz 2002.

Illg Jerzy, Niesamowitego spotkania karty nieznane. Korespondencja Tadeusza Micińskiego z Wincentym Lutosławskim, w: Studia o Tadeuszu Micińskim, M. Podraza-Kwiatkowska, Wydawnictwo Literackie, Kraków 1979, s. 341-402.

Jastrząbek Martyna, Muzyka w dramatach Tadeusza Micińskiego na przykładzie „Termopili polskich”. Misterium na tle życia i śmierci Księcia Józefa Poniatowskiego, „Acta Universitatis Lodziensis. Folia Litteraria Polonica” 2012, nr 1, s. 58-76.

Jonas Hans, Religia gnozy, przeł. M. Klimowicz, Wydawnictwo Platan, Kraków 1994. Koschmal Walter, Przekształcenie noweli w poemat prozą. „Pieśń tryumfującej miłości” I.S. Turgieniewa i T. Micińskiego, „Rocznik Komisji Historycznoliterackiej” 1990, t. XXVII, s. 171-176.

Krokiewicz Adam, Studia orfickie. Moralność Homera i etyka Hezjoda, Aletheia, Warszawa 2000.

Kubiak Zygmunt, Mitologia Greków i Rzymian, wyd. II popr., Świat Książki, Warszawa 1998.

Lurker Manfred, Słownik obrazów i symboli biblijnych, przeł. bp K. Romaniuk, Wydawnictwo Pallottinum, Poznań 1989. 
Miciński Tadeusz, Pieśń triumfującej miłości, w: Tadeusz Miciński, Poematy proza, oprac. W. Gutowski, Wydawnictwo Literackie, Kraków 1985, s. 47-62.

Miciński Tadeusz, Życie i twórczość w Hellerau, „Tygodnik Ilustrowany” 1912, nr 30 (z 27 lipca), s. 628-629.

Mit Orfeusza. Inspiracje $i$ reinterpretacje $w$ europejskiej tradycji artystycznej, red. S. Żerańska-Kominek, słowo/obraz terytoria, Gdańsk 2003.

Nowak Iwona, Muzyka w dramatach Tadeusza Micińskiego, „Acta Universitatis Lodziensis. Folia Litteraria Polonica" 2012, nr 1, s. 45-57.

Pigoń Stanisław, Niesamowite spotkanie literackie. Tadeusz Miciński - Wincenty Lutosławski, w: Stanisław Pigoń, Miłe życia drobiazgi, Państwowy Instytut Wydawniczy, Warszawa 1964, s. 405-454.

Podraza-Kwiatkowska Maria, Symbolizm i symbolika w poezji Młodej Polski, Wydawnictwo Literackie, Kraków 2001.

Prokop Jan, Żywioł wyzwolony. Studium o poezji Tadeusza Micińskiego, Wydawnictwo Literackie, Kraków 1978.

Przybyszewski Stanisław, Z psychologii jednostki twórczej. Chopin i Nietzsche, tłum. S. Helsztyński, w: Stanisław Przybyszewski, Wybór pism, oprac. R. Taborski, Zakład Narodowy im. Ossolińskich, Wrocław 1966, s. 3-36.

Ribot Théodule, Logika uczuć, tłum. K. Błeszyński, Krakowska Spółka Wydawnicza, Kraków 1921.

Rowiński Cezary, Orfeusz i Eurydyka, w: Mit - człowiek - literatura. Praca zbiorowa, red. S. Stabryła, Wydawnictwo Naukowe PWN, Warszawa 1992, s. 105-132.

Schopenhauer Artur, Świat jako wola i przedstawienie, przeł. J. Garewicz, t. 1-2, Wydawnictwo Naukowe PWN, Warszawa 2009.

Semczuk Antoni, Iwan Turgieniew, Wiedza Powszechna, Warszawa 1970.

Siwiec Magdalena, Orfeusz romantyków. Mit o Orfeuszu w twórczości Juliusza Słowackiego i Gérarda de Nerval w kontekście epoki, Universitas, Kraków 2002.

Sławińska Irena, Miciński i Hellerau, w: Studia o Tadeuszu Micińskim, red. M. Podraza-Kwiatkowska, Wydawnictwo Literackie, Kraków 1979, s. 303-323.

Sobolczyk Piotr, Tadeusza Micińskiego podróż do Hiszpanii, Wydawnictwo Adam Marszałek, Toruń 2005.

Suszka Cecylia, W poszukiwaniu utraconej jedni. O synkretyzmie kulturowo-religijnym w twórczości Tadeusza Micińskiego, „Ruch Literacki” 2001, z. 2, s. 165-182.

Tołstoj Lew, Sonata Kreutzerowska, tłum. M. Leśniewska, Książka i Wiedza, Warszawa 1987.

Wiedemann Adam, Sytuacja muzyki współczesnej $i$ wizje jej rozwoju w prozie powieściowej Młodej Polski, w: Stulecie Młodej Polski, studia pod red. M. Podrazy-Kwiatkowskiej, Wydawnictwo Literackie, Kraków 1995, s. 505-516.

Wydrycka Anna, Motywy gwiazd w liryce młodopolskiej, w: Poezja i astronomia, red. B. Burdziej, G. Halkiewicz-Sojak, Wydawnictwo UMK, Toruń 2006, s. $403-421$. 
Katarzyna Badowska

\section{Mit orfejski à rebours. O Pieśni tryumfującej miłości Tadeusza Micińskiego}

Streszczenie

Autorka interpretuje poemat prozą Tadeusza Micińskiego jako transpozycję mitu o Orfeuszu. Rozważaniami obejmuje przy tym nie tylko mit orfejski, ale i doktrynę orficką. Analizy sytuuje na szerokim tle podkreślającym znaczenie muzyki w Młodej Polsce. Odnotowuje kontakty pisarza z kompozytorami, reperkusje jego pobytu w Hellerau, a także utwory, w których tematyzował muzykę. W takiej perspektywie dokonuje analizy Pieśni tryumfującej miłości.

Słowa kluczowe: Mit o Orfeuszu i Eurydyce, muzyka w literaturze, Tadeusz Miciński, orfizm

\section{Pieśń tryumfującej miłości by Tadeusz Miciński as an inverted version of the Orpheus myth}

Summary

The author analyses Pieśń tryumfującej miłości (one the prose poems by Tadeusz Miciński) as an inverted version of the myth of Orpheus and Eurydice. The interpretation is embedded in the context of the Orphic doctrine and Orphic mystery cults. It refers also to the significant role of music - not only in the nineteenthcentury literature but also in Miciński’s life and work.

Keywords: The myth of Orpheus and Eurydice, Music in Literature, Miciński Tadeusz, Orphism 
Katarzyna Badowska - autorka książki „Godzina cudu”. Miłość i erotyzm w twórczości Stanisława Przybyszewskiego (2011), redaktorka takich tomów jak Liryka Młodej Polski. Interpretacje (2017), Przekleństwo i harmonia nieskończonego. Z zagadnień literatury Młodej Polski i epok późniejszych (2014), Ulica - zaułek - bruk. $Z$ problematyki miasta $w$ literaturze drugiej połowy XIX i początku XX wieku (2013). Zajmuje się literaturą przełomu XIX i XX wieku. 